Asia-Pacific Journal on Human Rights and the Law 


\section{Asia-Pacific Journal on Human Rights and the Law}

\section{Editors-in-Chief}

Simon N. M. Young, Faculty of Law, University of Hong Kong, Hong Kong

Kelley Loper, Faculty of Law, University of Hong Kong, Hong Kong

\section{Editorial Board}

Cora Chan, Faculty of Law, University of Hong Kong, Hong Kong

Agnes Chong, Faculty of Business and Economics, University of Hong Kong, Hong Kong

Mario Gomez, International Centre for Ethnic Studies, Colombo, Sri Lanka

Alex Green, York Law School, University of York, York, United Kingdom

James D. Fry, Faculty of Law, University of Hong Kong, Hong Kong

Puja Kapai, Faculty of Law, University of Hong Kong, Hong Kong

Karen Kong, Faculty of Law, University of Hong Kong, Hong Kong

Marco Wan, Faculty of Law, University of Hong Kong, Hong Kong

Student Editors: Trevor Wan, John Koo, Stephanie Chan, Janis Leung

\section{International Advisory Board}

Michael Davis, Woodrow Wilson International Center for Scholars; Jindal Global Law School

Fernand de Varennes, Former Editor-in-Chief; Université de Moncton, Canada

Jose Manuel Diokno, De La Salle University College of Law, Philippines

Lech Garlicki, Former Judge of the European Court of Human Rights; Faculty of Law, University of Hong

Kong; Warsaw University

Yash Ghai, Emeritus Professor, University of Hong Kong

Michael Kirby, Former Justice of the High Court of Australia; First Chairman of the Australian Law

Reform Commission

Carole J. Petersen, William S Richardson School of Law, University of Hawaii; Spark M Matsunaga

Institute for Peace and Conflict Resolution

Deepika Udagama, Former Chairperson, Human Rights Commission of Sri Lanka; Professor, University of Peradeniya

Volumes published in this journal are listed at brill.com/aphu 


\title{
Asia-Pacific Journal on Human Rights and the Law
}

\author{
VOLUME 23 (2022)
}

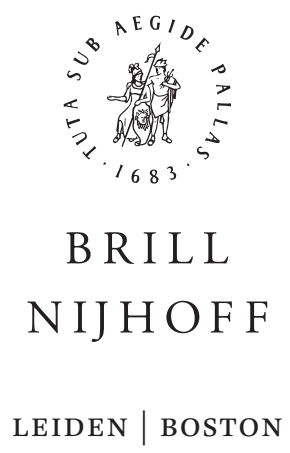


Brill Open Access options can be found at brill.com/openaccess.

Typeface for the Latin, Greek, and Cyrillic scripts: "Brill". See and download: brill.com/brill-typeface.

\section{ISSN 1388-1906}

E-ISSN 1571-8158

Copyright 2022 by Koninklijke Brill Nv, Leiden, The Netherlands.

Koninklijke Brill NV incorporates the imprints Brill, Brill Nijhoff, Brill Hotei, Brill Schöningh, Brill Fink, Brill mentis, Vandenhoeck \& Ruprecht, Böhlau Verlag and V\&R Unipress.

All rights reserved. No part of this publication may be reproduced, translated, stored in a retrieval system, or transmitted in any form or by any means, electronic, mechanical, photocopying, recording or otherwise, without prior written permission from the publisher. Requests for re-use and/or translations must be addressed to Koninklijke Brill NV via brill.com or copyright.com.

Brill has made all reasonable efforts to trace all rights holders to any copyrighted material used in this work. In cases where these efforts have not been successful the publisher welcomes communications from copyright holders, so that the appropriate acknowledgements can be made in future editions, and to settle other permission matters.

This journal is printed on acid-free paper and produced in a sustainable manner. 